Keywords:

Adsorption

Binding energy

Cellulose fiber

Nanocomposites

Nanowollastonite

Histórico:

Recebido 15/03/2016

Aceito 16/06/2016

Palavras chave: Adsorção Energia de ligação Fibra de celulose Nano compósitos Nano wollastonita

Correspondência: htaghiyari@srttu.edu

DOI:

\section{ADSORPTION OF NANOWOLLASTONITE ON CELLULOSE SURFACE: EFFECTS ON PHYSICAL AND MECHANICAL PROPERTIES OF MEDIUM- DENSITY FIBERBOARD (MDF)}

ABSTRACT: Effects of nanowollastonite (NW) adsorption on cellulose surface were studied on physical and mechanical properties of medium-density fiberboard (MDF) panels; properties were then compared with those of MDF panels without NW-content. The size range of NW was $30-110 \mathrm{~nm}$. The interaction between NW and cellulose was investigated using density functional theory (DFT). Physical and mechanical tests were carried out in accordance with the Iranian National Standard ISIRI 9044 PB Type P2 (compatible with ASTM DI037-99) specifications. Results of DFT simulations showed strong adsorption of NW on cellulose surface. Moreover, mechanical properties demonstrated significant improvement. The improvement was attributed to the strong adsorption of NW on cellulose surface predicted by DFT, adding to the strength and integrity between wood fibers in NW-MDF panels. It was concluded that NW would improve mechanical properties in MDF panels as a wood-composite material, as well as being effective in improving its biological and thermal conductivity.

\section{ADSORÇÃO DE NANO WOLLASTONITA NA SUPERFÍCIE DE CELULOSE: EFEITOS NAS PROPRIEDADES FÍSICAS E MECÂNICAS DE PLACAS DE FIBRA DE MADEIRA DE MÉDIA DENSIDADE (MDF)}

RESUMO: Efeitos da adsorção de nano wollastonite (NW) na superfície de celulose foram estudados nas propriedades físicas e mecânicas de placas de fibra de madeira de média densidade (MDF); as propriedades foram então comparadas com aqueles de painéis de MDF sem NW. A amplitude de tamanho de NW foi 30-II0 nm. A interação entre NW e celulose foi investigada usando a teoria do funcional da densidade (DFT). Foram efetuados testes físicos e mecânicos em conformidade com as especificações do Iranian Nacional Standard ISIRI 9044 PB tipo P2 (compatível com ASTM DI037-99). Resultados de simulações de DFT mostraram forte adsorção de NW em superfície de celulose. Além disso, propriedades mecânicas demonstraram melhora significativa. A melhoria foi atribuída à forte adsorção de NW na superfície de celulose prevista pela DFT, agregando força e integridade entre fibras de madeira de painéis de MDF com NW. Concluiu-se que NW melhora propriedades mecânicas em painéis MDF como um material compósito de madeira, além de ser eficaz em melhorar a sua condutividade térmica e biológica.

I Shahid Rajaee Teacher Training University - Tehran, Lavizan, Iran 


\section{INTRODUCTION}

Fast-growing species provide an opportunity to satisfy the increasing needs for wood and wood products (FERNANDEZ et al, 20l4). However, they are usually harvested very young and therefore the stem diameter is not large. Therefore, they are usually used in composite and paper manufacturing industries. In this connection, composite-boards have the advantage of offering a homogeneous structure which may be important for many design purposes (ESHAGHI et al, 20I3). However, composite manufacturing factories always suffers from problems, such as: transferring heat to the core section of the mat, formaldehyde emission, water absorption, thickness swelling, etc. In order to overcome these problems, many studies have been carried out to limit formaldehyde emissions and resin-bond improvement (STOCKEL et al, 2012; VALENZUELA et al, 2012; MENDES et al, 2013). Heat-transferring property of metal nanoparticles (KHOJIER et al, 20I2; SABER et al, 20I3) suspended in liquid (DRELISH, 20I3) were also reported to both decrease hot press time and improve physical and mechanical properties in wood-composite panels. In this sense, wollastonite nanofiber (as a silicate mineral, $\mathrm{CaSiO}_{3}$ ) was reported to improve dimensional stability in solid woods (HAGHIGHI et al, 20I3), to increase biological durability to fungal rot in solid woods (MARESI et al, 20I3), to improve biological resistance against wood-deteriorating fungi in wood-composites (TAGHIYARI et al, 20I4), as well as to increase thermal conductivity coefficient in medium-density fiberboard (MDF) (TAGHIYARI et al, 20I3). However, few studies have been made on the effects of nanowollastonite (NW) on physical and mechanical properties in MDF panels and how NW interacts with wood fibers or particles in wood-composite panels. The present research project was done to theoretically study adsorption of NW on cellulose in wood fibers, and experimentally investigate its possible effects on physical and mechanical properties in MDF panels.

\section{MATERIALS AND METHODS}

\section{Specimen Procurement}

Wood fibers were procured from Sanaye Choobe Khazar Company in Iran (MDF Caspian Khazar). The fibers comprised a mixture of five species of beech, alder, maple, hornbeam, and poplar from the neighboring forests. Stop-bars of $16 \mathrm{~mm}$ were used on both sides of the mat so that the final MDF panels were $16 \mathrm{~mm}$ in thickness and $0.67 \mathrm{~g} \cdot \mathrm{cm}^{-3}$ in density (Figure I). The total nominal pressure of the plates was 160 bars. The temperature of the plates was fixed at $175^{\circ} \mathrm{C}$. Hotpressing continued for 6 minutes. Urea-Formaldehyde resin (UF), as a popular thermosetting resin in composite manufacturing factories of Iran, was procured from Pars Chemical Industries Company, Iran. 10\% of UF with 200-400 cP in viscosity, 47 seconds of gel time, and $1.277 \mathrm{~g} / \mathrm{cm}^{3}$ in density was used. Specimens were kept in conditioning chamber $\left(25^{\circ} \mathrm{C}\right.$, and $40 \pm 3 \%$ Relative Humidity) for four weeks before the tests were carried out on them. The moisture content of the specimens at the time of testing was $7.5 \%$ because wood has a thermo-hygromechanical behavior and its properties depend on the combined action of temperature, relative humidity, and mechanical load variations (FIGUEROA et al, 20I2). Five boards were made for both the control and NW-added treatments. From each board, two specimens were cut for each kind of test; therefore, there were totally 10 specimens for each test.

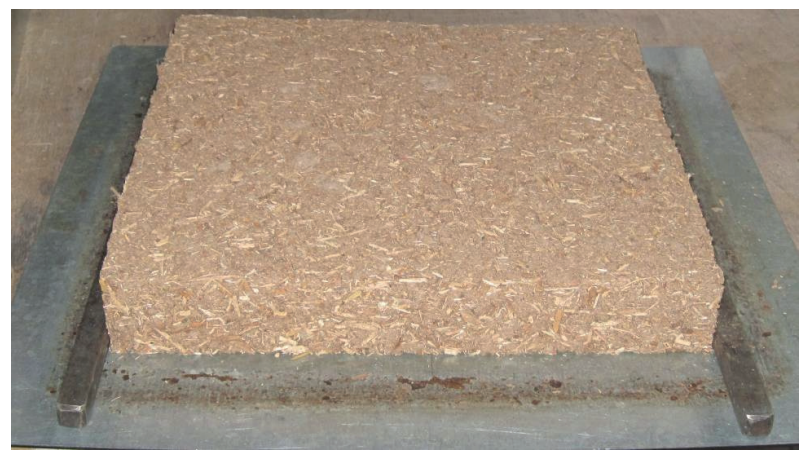

FIGURE I Photograph of fiberboard mat formation, ready to be put under the hot-press.

\section{Nanowollastonite Application}

NW gel was produced in cooperation with Vard Manufacturing Company of Mineral and Industrial Products in the Southern Khorasan province, Iran. The size range of wollastonite nanofibers was $30-110 \mathrm{~nm}$. NW was mixed with the UF resin and sprayed on to the wood fibers in a drum-mixer before the hot press. A magnetic mixer stirred the mixture for half an hour for each load of the drum-mixer. Previous studies indicated that the optimum level for consumption of wollastonite gel was 10\% (TAGHIYARI et al, 2013; TAGHIYARI et al, 20।4; TAGHIYARI AND SARVARI SAMADI, 20I6) based on the dry weight of the UF-resin used in MDF panels. They reported that this consumption level resulted in the best properties; boards with higher consumption levels resulted in blows in the composite panels. 


\section{Physical and Mechanical Tests}

Physical and mechanical tests, as well as number and location of the specimens, were carried out in accordance with the Iranian National Standard ISIRI 9044 PB Type P2 (compatible with ASTM DI037-12) specifications, using INSTRON 4486 test machine, with $5 \mathrm{KN}$ capacity. Modulus of rupture (MOR) and modulus of elasticity (MOE) were calculated using equation I and 2 , respectively, where $L$ is the maximum load, $L$ is the major span, $b$ and $d$ are the specimen width and depth respectively, $D$ is the tangent of the slope angle of the load vs. deflection curve during elastic deformation Three-point static flexural tests were performed to measure modulus of rupture (MOR) and modulus of elasticity (MOE). Nominal sizes of the specimens were $380 \times 70 \times 1.6$ $\mathrm{mm}$, with loading speed of $5 \mathrm{~mm} \cdot \mathrm{min}^{-1} .20$ samples of the same location for each treatment were tested using an INSTRON 4486 test machine, with $5 \mathrm{KN}$ capacity.

$$
\begin{aligned}
& \text { MOR }=\frac{1.5 F L}{b d^{2}} \\
& M O E=\frac{F L^{3}}{4 b d^{3} D}
\end{aligned}
$$

Hardness was measured using a modified Janka ball. The diameter of the modified ball was $11.28 \mathrm{~mm}$, with a projected area of $100 \mathrm{~mm}^{2}$. Dimensions of the hardness specimens were $75 \times 150 \mathrm{~mm}$. Two test specimens were bound together to provide the final thickness of $32 \mathrm{~mm}$; this was done in order to meet the required minimum thickness of $25 \mathrm{~mm}$ as specified in the standard. Two penetrations were made on each of the flat faces of the specimens, the average of which was considered final for statistical purposes. Loading test was applied at a uniform rate of $4 \mathrm{~mm} \cdot \mathrm{min}^{-1}$. Hardness was measured at four different penetration depths of the hardness ball; that is, hardness loading was measured at $3,4,5$, and $5.4 \mathrm{~mm}$ of the penetration of the ball into the composite-board specimens (TAGHIYARI AND NORTON, 20I4).

\section{Theoretical Details}

Density functional theory (DFT) calculations were performed using OpenMX3.6 package (OZAKI et al, 20I I) to study adsorption of NW on cellulose surface and understand the origins of changes in physical and mechanical properties of NW-MDF. The generalized gradient approximation (GGA) function with the PerdewBurke-Ernzerhof (PBE) correction was used to describe the exchange-correlation energy functional (Perdew et al. 1996). The van der Waals (vdW) interactions were included by DFT-D2 approach proposed by Grimme (GRIMME 2006). The cutoff energy of the plane wave basis was set to be 50 Ry.

The atomic structures of cellulose and wollastonite were taken from X-ray and neutron fiber diffraction experiments (NISHIYAMA et al, 2002; OHASHI, 1984). The lattice parameters of unit cells of cellulose $\mathrm{I} \beta$ and wollastonite $2 M$ are listed in Table I. As the host material for NW adsorption, (100) surface of $2 \times 2$ cellulose chains (Figure $2 A$ ) was studied. A slab consisting of three layers of cellulose chains was cleaved from bulk cellulose. The unit cell of wollastonite contains two chains of tilted $\mathrm{SiO}_{4}$ tetrahedral groups along $b$-axis with $\mathrm{Ca}$ atoms inserted between them (RICHARDSON, 1999; BUERGER, 1956). One layer of wollastonite with six $\left(\mathrm{CaSiO}_{3}\right)_{3}$ units (Figure 2B) was considered to adsorb on the (I00) surface of cellulose. A simulation box consisting of monolayer NW and trilayer cellulose was considered (Figure 2C). The periodic boundary conditions were applied in all directions. A vacuum space of about $10 \AA$ was taken along the $x$ direction in a supercell to avoid interactions between neighboring supercells. To model water adsorption on cellulose surface, a monolayer of water with I to 30 water molecules was considered on the (100) cellulose surface. As an example, a simulation box with 9 water molecules is shown in Figure 2D.

To evaluate the interaction between NW and cellulose surface, adsorption energy, $E_{\text {ads }}[3]$, was calculated by, where $E_{\text {cellulose }+N W}$ represents the total energy of cellulose with adsorbed NW, $E_{\text {cellulose }}$ and $E_{N W}$ are the total energies of an isolated cellulose slab and an isolated NW, respectively. The negative adsorption energy corresponds to a stable adsorption structure.

$$
\mathrm{E}_{\text {ads }}=\mathrm{E}_{\text {cellulose }+\mathrm{NW}}-\left(\mathrm{E}_{\text {cellulose }}+\mathrm{E}_{\mathrm{NW}}\right)
$$

TABLE I The lattice parameters of unit cells of cellulose I $\beta$ and wollastonite 2M (NISHIYAMA et al, 2002; OHASHI, 1984).

\begin{tabular}{llllllll}
\hline & & $\mathrm{a}(\AA)$ & $\mathrm{b}(\AA)$ & $\mathrm{c}(\AA)$ & $\alpha$ & $\beta$ & $\gamma$ \\
\hline $\begin{array}{l}\text { Cellulose } \mathrm{I} \beta \\
\left(\mathrm{C}_{6} \mathrm{H}_{10} \mathrm{O}_{5}\right)_{4}\end{array}$ & 7.78 & 8.2 & 10.37 & $90^{\circ}$ & $90^{\circ}$ & $96.55^{\circ}$ \\
$\begin{array}{l}\text { Wollastonite } \\
2 \mathrm{M}\end{array}$ & $\left(\mathrm{CaSiO}_{3) 3}\right.$ & 15.424 & 7.32 & 7.062 & $90^{\circ}$ & $95.37^{\circ}$ & $90^{\circ}$ \\
\hline
\end{tabular}

\section{Statistical Analysis}

Statistical analysis was conducted using SPSS16 software program. Independent sample T-test was performed to discern significant difference at the $95 \%$ level of confidence. 
A

B $\rightarrow z$
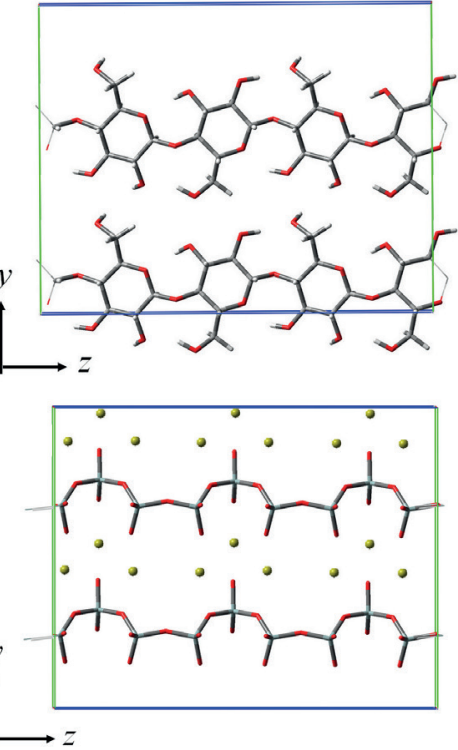

C

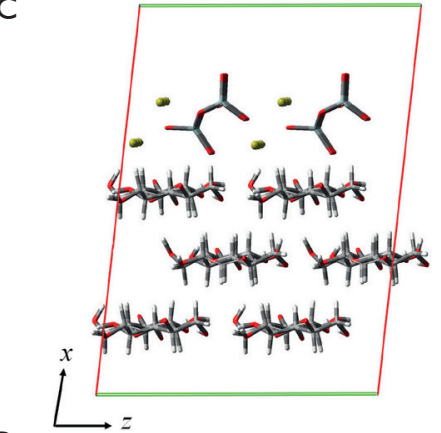

D

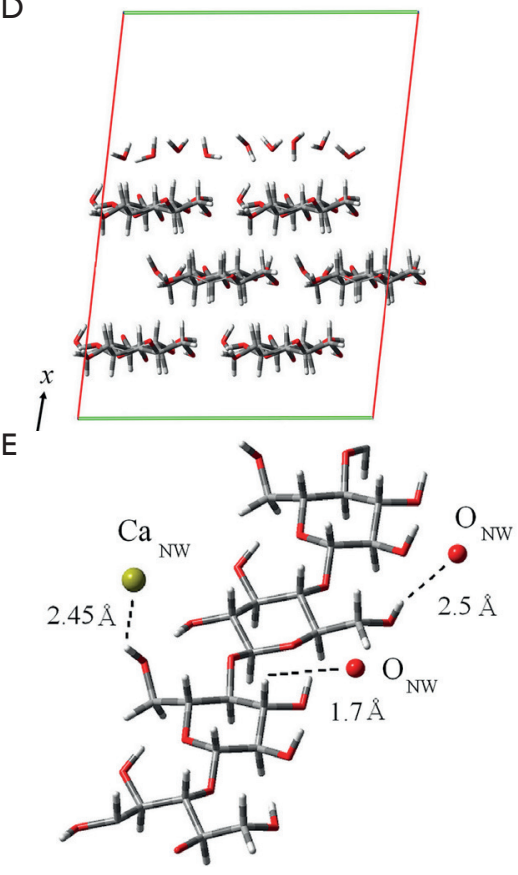

FIGURE 2 Top view of one layer of cellulose (A) and wollastonite (B), side view of nanowollastonite (C) and water (D) adsorbed on the (100) surface of cellulose, and schematic representation of bonds between $\mathrm{Ca}$ and $\mathrm{O}$ atoms of $\mathrm{NW}$ with cellulose chain $(\mathrm{E})$.

\section{RESULTS AND DISCUSSION}

\section{Adsorption of Nanowollastonite and Water on Cellulose Surface}

Different configurations for NW on cellulose were constructed by floating and rotating NW on cellulose surface. Adsorption energy of these different configurations was calculated. The configuration with the lowest adsorption energy was chosen as the most stable configuration (Figure 2C). NW was then vertically moved toward and away from cellulose surface. To find optimal distance between NW and cellulose, adsorption energy as a function of the nearest distance between NW and cellulose surface was calculated (Figure 3). The minimum point of this curve showed the optimal adsorption distance and adsorption energy of $1.7 \AA$ and $-6.6 \mathrm{eV}$, respectively. The large adsorption energy indicated strong adsorption of NW on cellulose surface and formation of bonds between them. The bond between $\mathrm{Ca}$ in NW and hydroxyl groups in cellulose chains was most responsible for the strong adsorption of NW on cellulose surface. The hydrogen bonding between cellulose and NW $\left(\mathrm{OH} \ldots \mathrm{O}_{\mathrm{NW}}\right.$ and $\mathrm{CH} . . . \mathrm{O}_{\mathrm{NW}}$ ) were also found to be effective in holding NW on cellulose surface. The main bonds formed between NW and cellulose surface and their bond lengths are schematically shown in Figure 2D. It should, however, be noted that the improvements in the mechanical properties were also partially related to an increase in the thermal conductivity coefficient of NW-MDF panels by the addition of wollastonite nanofibers (TAGHIYARI et al, 20I3). In this connection, further studies should be carried out to finalize to what extent either of the improving causes (the formation of bonds, and the increase in thermal conductivity coefficient) affected the results.

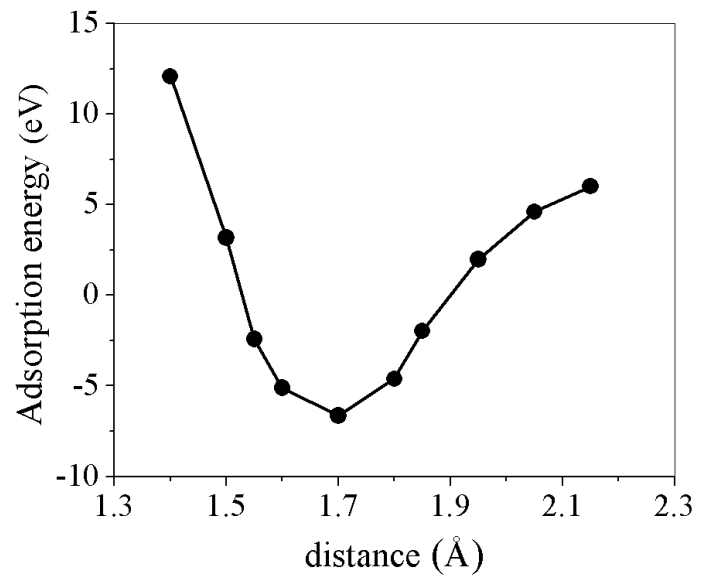

FIGURE 3 Adsorption energy $(\mathrm{eV})$ as a function of nearest distance between nanowollastonite and cellulose $(\AA)$. 
The cellulose chains are terminated by hydroxyl groups and their (100) surface exposes exclusively $\mathrm{CH}$ moieties to the surrounding medium (LI et al. 20I I). Adsorption of a single water molecule on different functional groups of cellulose surface was studied to clarify formation of hydrogen bond between water and cellulose. It was found that various types of hydrogen bonds $\left(\mathrm{OH}_{\text {water }} \ldots \mathrm{O}, \mathrm{OH}_{\text {water }} \ldots \mathrm{OH}\right.$, and $\left.\mathrm{OH}_{\text {water }} \ldots \mathrm{CH}\right)$ were formed between water molecule and cellulose surface; $\mathrm{OH}_{\text {water }}$ indicated the hydroxyl group of adsorbed water molecule. The hydrogen bond lengths were calculated to be between 1.6 and $1.8 \AA$ with adsorption energy between -0.22 and $-0.28 \mathrm{eV}$ per unit cell of cellulose. For water adsorption on cellulose surface, adsorption energy as a function of the number of water molecules is shown in Figure 4. It was found that increasing the number of adsorbed water molecules leads to an increase in the absolute value of the adsorption energy as a consequence of the increase in the number of hydrogen bonds between water and cellulose surface.

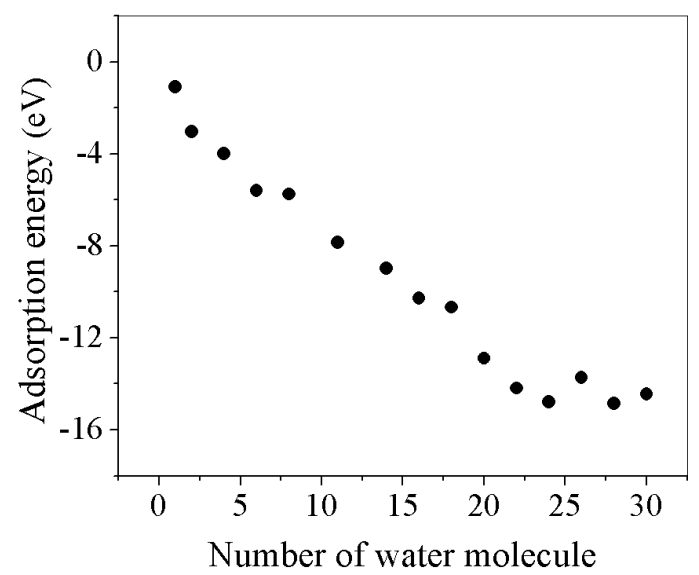

FIGURE 4 Adsorption energy $(\mathrm{eV})$ as a function of the number of water molecule.

The hydrogen bonding can form between NW and cellulose surface only when one oxygen atom of NW comes in close contact with $\mathrm{OH}$ and $\mathrm{CH}$ groups from cellulose surface. In the presence of water, the abundant hydroxyl groups in water molecules can significantly increase the number of hydrogen bonds between water and cellulose surface. The competition between water and NW to form bond with cellulose surface may lead to a less favorable interaction between NW and cellulose surface and consequently separation of NW from cellulose. In the present research project, further experimental studies were performed to elucidate the effect of water on adsorption of NW on cellulose and the physical properties of NW-MDF panels.

\section{Effect of Nanowollastonite on Mechanical Properties}

Calculations of modulus of rupture (MOR) showed significant increase $(27 \%)$ in panels as a result of addition of NW in the composite combination. MOR values for the control and NW-treated panels were 0.36 and $0.46 \mathrm{MPa}$, respectively (Figure 5A). Results of modulus of elasticity (MOE) tests showed similar improvement $(5 \mathrm{I} .7 \%)$ in MOE values (Figure 5B); II59 and $1760 \mathrm{MPa}$ for the control and NW-treated panels, respectively. Addition of wollastonite nanofibers to the wood-composite matrix did not show as much improvement on brittleness as in MOR and MOE, though the values illustrated a slight improvement (9.7\%) (Figure 5C).

Hardness values demonstrated no significant difference between the control versus NW-treated panels in any of the four depths of penetration of the modified Janka ball (Figure 5D). The force to insert the ball into MDF composite matrix significantly increased as the depth of penetration increased.

Mechanical properties of MOR and MOE demonstrated significant improvement in NW-panels. This indicated the positive effect of formation of interaction between wollastonite nanofibers and cellulose surface as predicted by DFT; that is, the interactions acted as secondary bonds among fibers adding to the strength of bonds already formed by the UF-resin used in the NW-MDF matrix. SEM micrographs of the surface of the panels showed the fibers were stuck together with more integrity in the NW-MDF panels (Figure 6A) than those on the surface of the control panels (Figure 6B). In fact, some fibers seemed to be loose on the surface of the control panels.

Hardness, on the other hand, showed no distinct alteration as a result of addition of NW to MDF panels. This was due to the fact that hardness is more related to the mechanical hardness of the main components of MDF panels. That is, the NW content of wollastonite was very low (only 10\% of the UF-resin, used), as well as being broken to nanoscale; therefore, wollastonite nanofiber could not possibly add to the hardness of the NW-MDF panels.

The improvement in the mechanical properties was also partially attributed to the increase in the thermal conductivity coefficient of NW-panels (TAGHIYARI et al, 20I3). Woody components have basically very low thermal conductivity coefficient, making it difficult for the heat to be transferred from the hot-press plates to the composite mat (TAGHIYARI et al, 2013). Addition of materials with high thermal conductivity coefficients (metals such as copper and silver, and minerals such as 
A

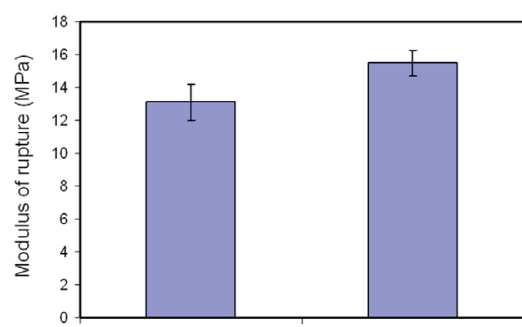

B

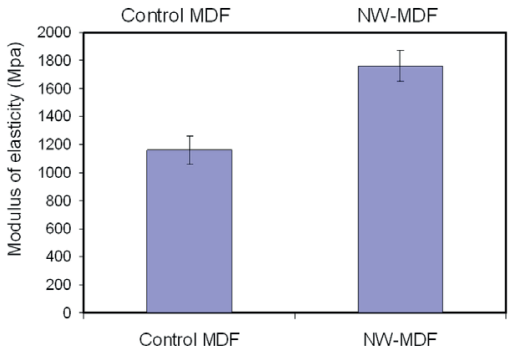

C

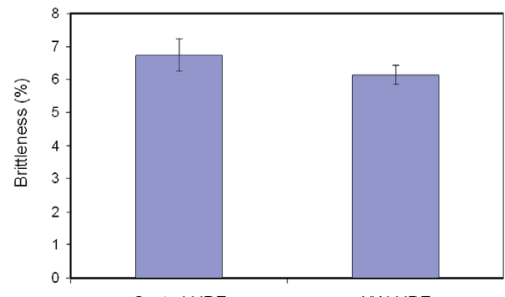

D

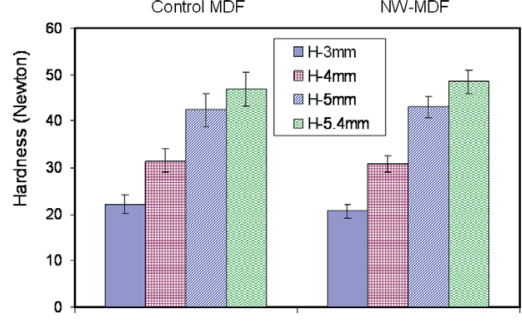

Control MDF

NW-MDF

$E$

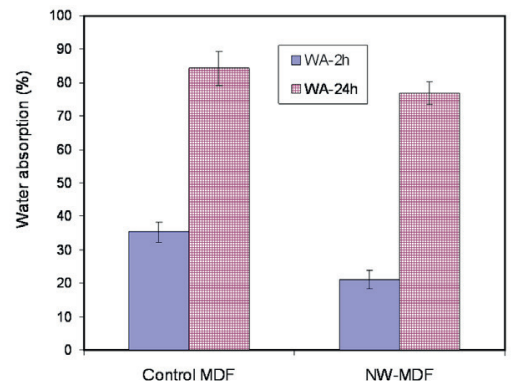

$\mathrm{F}$

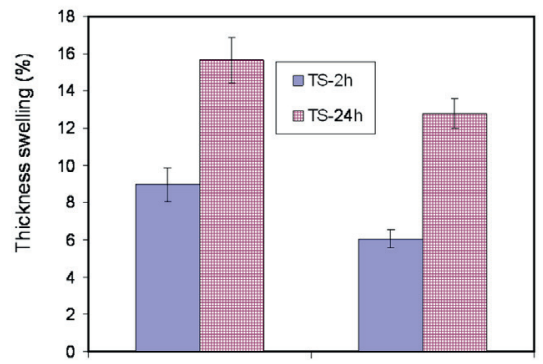

FIGURE 5 Modulus of rupture $(\mathrm{MPa})(\mathrm{B})$, Modulus of elasticity (MPa) (B), Brittleness (\%) (C), Hardness (Newton) at 3, 4,5 , and $5.4 \mathrm{~mm}$ depths of penetration of the modified Janka ball (D), Water absorption (\%) (E), and Thickness swelling (\%) (F) in medium-density fiberboard panels (NW= panels containing $10 \%$ nanowollastonite). wollastonite) helped increasing the thermal conductivity coefficient (TAGHIYARI AND NORTON, 20I4). This increase helped to better transfer heat from the hot plates, resulting in better and faster polymerization and curing of the UF-resin, eventually improving the mechanical properties.

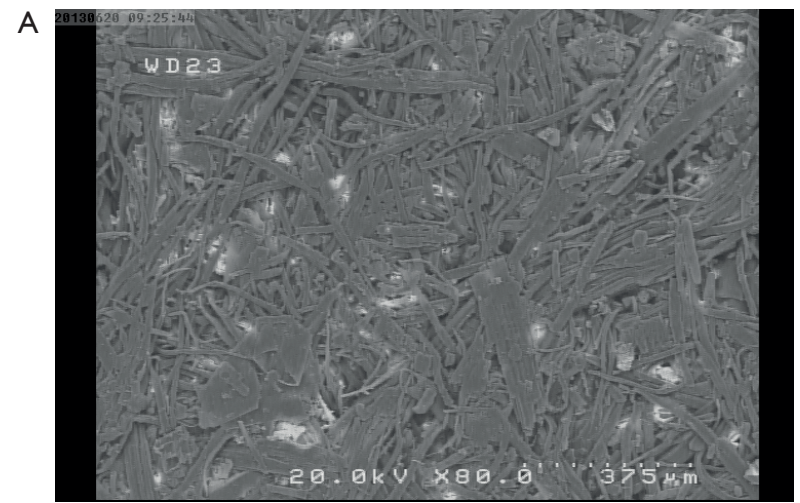

B

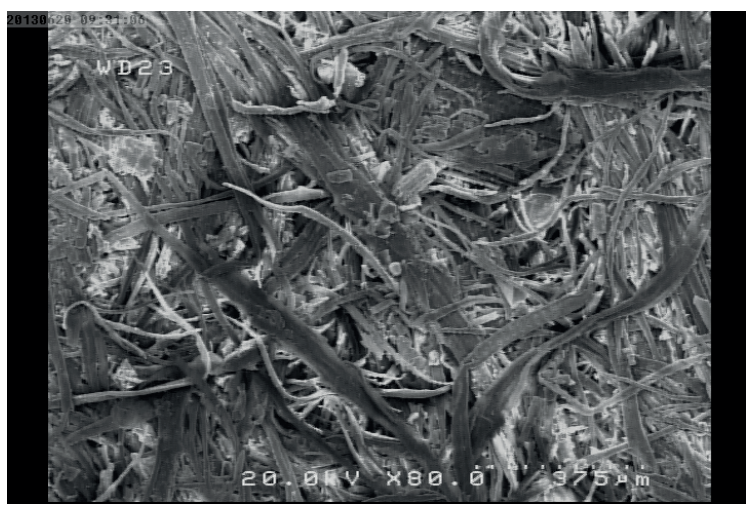

FIGURE 6 SEM micrographs of the surface of the NW-MDF (A) and the controls panels (B).

\section{Effect of Nanowollastonite on Physical Properties}

Results showed that NW decreased water absorption (WA) after both 2 and 24 hours immersion in distilled water (Figure 5E). WA of NW-treated panels was $66.5 \%$ and $9.6 \%$ lower than the control panels after 2 and 24 hours, respectively. Thickness swelling (TS) showed similar decreasing trend (Figure 5F); only the decreased values were different in comparison to WA. TS of NW-MDF panels were $48.7 \%$ and $22.6 \%$ lower than the control panels after 2 and 24 hours, respectively.

Both physical properties showed significant difference between the control versus NW-MDF panels after 2 hours of immersion in distilled water. This demonstrated strong adsorption of NW on cellulose as described by DFT calculations. However, as the duration of immersion in distilled water extended to 24 hours, the difference between the control and NW-panels 
seemed to decrease significantly. In this connection, absorption of water by hydroxyl groups in cell wall components (mostly the hydroxyl groups of cellulose and hemi-cellulose), resulted in the gradual breakage of bonds between NW and cellulose, eventually WA and TS in NW-panels increased significantly to be close to the control panels. In fact, after 24 hours immersion in water, the hydrogen bond network on cellulose surface was dominated by bonds with the abundant and small water molecules, consequently NW bonds were substituted by water bonds on cellulose surface. It was therefore concluded that NW can significantly improve some of the mechanical properties such as MOR and MOE however, careful attention should be taken not to use NW-treated MDF panels in humid environment as the breakage of bonds between NW and cellulose by water molecules results in significant decrease in mechanical properties.

\section{CONCLUSION}

Theoretical adsorption of NW on cellulose surface by density functional theory (DFT) predicted a strong interaction and formation of bonds between NW and cellulose surface. Experimental results demonstrated improved mechanical properties in MDF. The improvement in mechanical properties was partially attributed to an increase in thermal conductivity of the composite mat, facilitating the transfer of heat from hot-press plates to the center of the mat, eventually enhancing resin curing. Immersion in distilled water to measure water absorption and thickness swelling showed that the bonds formed through the adsorption of NW on cellulose surface substituted by abundant water molecules over time.

\section{ACKNOWLEDGMENTS}

The present study was financed by Shahid Rajaee Teacher Training University (SRTTU), for which the authors are grateful.

\section{REFERENCES}

BUERGER, M. J. The arrangement of atoms in crystals of the wollastonite group of metasilicates. Proceedings of the National Academy of Sciences, v. 42, n. 3, p. I I 3- I I6, 1956.

DRELISH,J. Nanoparticles in a liquid: New state of liquid. Journal of Nanomaterials \& Molecular Nanotechnology, v. 2, n. I, p. I-2, 2013.

ESHAGHI, S.; FAEZIPOUR, M.; TAGHIYARI, H. Investigation on lateral resistance of joints made with drywall and sheet metal screws in bagasse particleboard and comparison with that of commercial MDF. Maderas. Ciencia y tecnología, v. I5, n. 2, p. I27-I40, 2013.
FERNÁNDEZ-PURATICH, H.; OLIVER-VILLANUEVA, J. V. Cuantificación de biomasa y valor energético de renovales de Quercus ilex en condiciones mediterráneas. Bosque (Valdivia), v. 35, n. I, p. 13-14, 2014.

FIGUEROA, M.; BUSTOS, C.; DECHENT, P.; REYES, L.; CLOUTIER, A.; E GIULIANO, M. Análisis del comportamiento reológico y termo-higromecánico en probetas de tableros tensados de madera para puentes a condiciones ambientales variables. Maderas. Ciencia y tecnología, v. 14 n. 3, p. 303-319, 2012.

GRIMME, S. Semiempirical GGA-type density functional constructed with a long-range dispersion correction. Journal of Computational Chemistry, v. 27, p. I787-I799, 2006.

HAGHIGHI, A. P.; TAGHIYARI, H.; RKARIMI, A. N. The optimum level of nano-wollastonite consumption as fireretardant in poplar wood (Populus nigra). International Journal of Nano Dimension (IJND), v. 4, n. 2, p. I4II5I, $20 \mid 3$.

KHOJIER, K.; ZOLGHADR, S.; ZARE, N. Structural, electrical, and optical properties of molybdenum oxide thin films prepared by post-annealing of Mo thin films. International Journal of Bio-Inorganic Hybrid Nanomaterials, v. I, n. 3, p. 199-207, 2012.

LI, Y.; DAVENPORT, J. W. Ad initio studies of cellulose: Crystal structure, intermolecular forces, and interactions with water. The Journal of Physical Chemistry C, v. II5, p. II533 - II539, 201 I.

MARESI, G.; OLIVEIRA LONGA, C. M.; TURCHETTI, T. Brown rot on nuts of Castanea sativa Mill: an emerging disease and its causal agent. iForest-Biogeosciences and Forestry, v. 6, n. 5, p. 294-30I, 2013.

MENDES, R. F.; BORTOLETTO JÚNIOR, G.; ALMEIDA, N. F; SURDI, P.; BARBEIRO, I. Effects of thermal pre-treatment and variables of production on properties of OSB panels of Pinus taeda. Maderas. Cienciay tecnologia, v. I5, n. 2, p. |4I-I52, 2013.

NISHIYAMA, Y.; LANGAN, P.; CHANZY, H. Crystal Structure and Hydrogen-Bonding System in Cellulose $I \beta$ from Synchrotron X-ray and Neutron Fiber Diffraction. Journal of the American Chemical Society, v. 124, n. 31, p. 9074-9082, 2002.

OHASHI, Y. Polysynthetically-twinned structures of enstatite and wollastonite. Physics and Chemistry of Minerals, v. 10, n. 5, p. 217-229, 1984.

PERDEW, J. P.; BURKE, K.; ERNZERHOF, M. Generalized Gradient Approximation Made Simple. Physical review letters, v. 77, n. 18, p. 3865-3868, 1996.

RICHARDSON, I.G. The nature of C-S-H in hardened cements. Cement and Concrete Research, v. 29, n. 8, p. II3III47, 1999. 
SABER, R.; SHAKOORI, Z.; GILL, P.; TAVOOSIDANA, G.; KHARRAZI, S.; SARKAR, S. Spectroscopic and microscopic analyses of rod-shaped gold nanoparticles interacting with single-stranded DNA oligonucleotides. IET Nanobiotechnology, v. 7, n. 2, p. 42-49, 2013.

STÖCKEL, F; KONNERTH, J.; MOSER, J.; KANTNER, W.; GINDL-ALTMUTTER, W. Micromechanical properties of the interphase in pMDI and UF bond lines. Wood Science and Technology, v. 46, n. 4, p. 6II-620, $201 \mathrm{l}$.

TAGHIYARI, H. R.; SAMADI, Y. S. Effects of wollastonite nanofibers on fluid flow in medium-density fiberboard. Journal of Forestry Research, v. 27, n. I, p. 209-217, 2016.

TAGHIYARI, H. R.;NORTON, J. Effect of silver nanoparticles on hardness in medium-density fiberboard (MDF). iForestBiogeosciences and Forestry, v. 8, n. 5, p. 677-680, 2015.
TAGHIYARI, H. R.; BARI, E.; SCHMIDT, O.; TAJICK GHANBARY, M.; KARIMI, A.; TAHIR, P. M. D. Effects of nanowollastonite on biological resistance of particleboard made from wood chips and chicken feather against Antrodia vaillantii. International Biodeterioration \& Biodegradation, v. 90, p. 93-98, 2014.

TAGHIYARI, H. R.; MOBINI, K.; SAMADI, Y. S.; DOOSTI, Z.; NOURI, P. Effects of Nano-Wollastonite on Thermal Conductivity Coefficient of Medium-Density Fiberboard. Journal of Nanomaterials \& Molecular Nanotechnology, v. 02, n. 01, 2013.

VALENZUELA, J.; VON LEYSER, E.;PIZZI, A.;WESTERMEYER, C.; GORRINI, B. Industrial production of pine tanninbonded particleboard and MDF. European Journal of Wood and Wood Products, v. 70, n. 5, p. 735-740, 2012. 